\title{
シングルチャンネル人工内耳：3 症例の経験とその臨床成績
}

\author{
愛媛大学医学部耳鼻咽喉科学教室（主任：柳原尚明教授） \\ 暗清 文, 佐 藤 英光, 竹田一彦, 柳 原尚 明
}

\section{SINGLE CHANNEL COCHLEAR IMPLANT : APPLICATION TO THREE PATIENTS}

\author{
KIYOFUMI GYO, M.D., HIDEMITSU SATO, M.D., KAZUHIKO TAKEDA, M.D. \\ and NAOAKI YANAGIHARA, M.D.
}

Department of Otolaryngology, Ehime University School of Medicine, Ehime

\begin{abstract}
Single channel cochlear implant of $3 \mathrm{M} /$ House design was implanted to the three patients with profound hearing loss. Before the implantation, use of hearing aid had not afforded serviceable hearing enough for speech recognition in these patients. Postoperative courses were uneventful. Speech rehabilitation was started at 3 weeks after the surgery. The speech tracking scores with the cochlear implant plus lipreading achieved $20-25$ bunsetues (the minimum meaningful unit of the Japanese sentence) per minite at three or four months after the operation. All the patients could recognize speech of daily life with help of lipreading. However, speech recognition by the cochlear implant alone was not satisfactory.
\end{abstract}

Key words : 人工内耳, 聴能訓練, 復唱検査, 言語聴取能

A $92-1042-23598$

\section{I .はじめに}

聴賞は視覚とともに社会生活を送る上で重要な感賞 である、聴覚に障害がおこると周囲の人々とのコミュ ニケーションが十分にとれなくなり，難聴者は社会か ら隔離され孤独感を抱くことになる。とりわけ難聴が 高度の場合には会話が全く不可能となり, 通常の社会 生活を送ることさえ困難になる。従来より難聴に対し ては補聴器が用いられてきたが，高度難聴者には全く 効果がなかった。このような患者に対して開発された のが人工内耳（Cochlear Implant）である.人工内耳 は高度内耳性難聴者の蝸牛内あるいはその近傍に電極 を埋め込み, 残存している蝸牛神経を電気刺激するこ とによって音を聞かせる装置である。これによりこれ まで医学的に治療方法のなかった俩の患者に音を聞か せることが可能となった。しかしながら，人工内耳の 臨床応用はわが国では始まったばかりでありいー7, 日 本語の会話における効果については充分に研究されて いない.
今回, 我々は 3 例の高度内耳性難聴者にシングルチ ヤンネル人工内耳を植え込み、リハビリテーションを 行う機会を得た。この方式の人工内耳による言語聴取 能の回復効果とその限界, 副作用等について検討した ので報告する。

\section{II . 装置の概要}

今回使用したのは米国スリーエム社製のアルファ型 人工内耳で, その主要構成要素は次の 4 つの部分から 成る.すなわち，音を拾うマイクロホン，その音を電 気刺激用の信号に变換するプロセッサー, 体外から体 内に信号を送る信号伝達装置, および蝸牛神経に電気 信号を伝える電極である。図 1 に本装置の回路図を示 $す 8)$. 信号伝達装置は体外部の発信機 (体外コイル) と 体内に埋め込む受信機（体内コイル）とからなり，信 号は電磁誘導で伝達される。両者は中心部に強力な磁 石を持占，皮膚を介してくっつき合う。体内コイルは 直径 $19.9 \mathrm{~mm}$, 厚さ $3.8 \mathrm{~mm}$ のコン状で, 全体はチ夕 


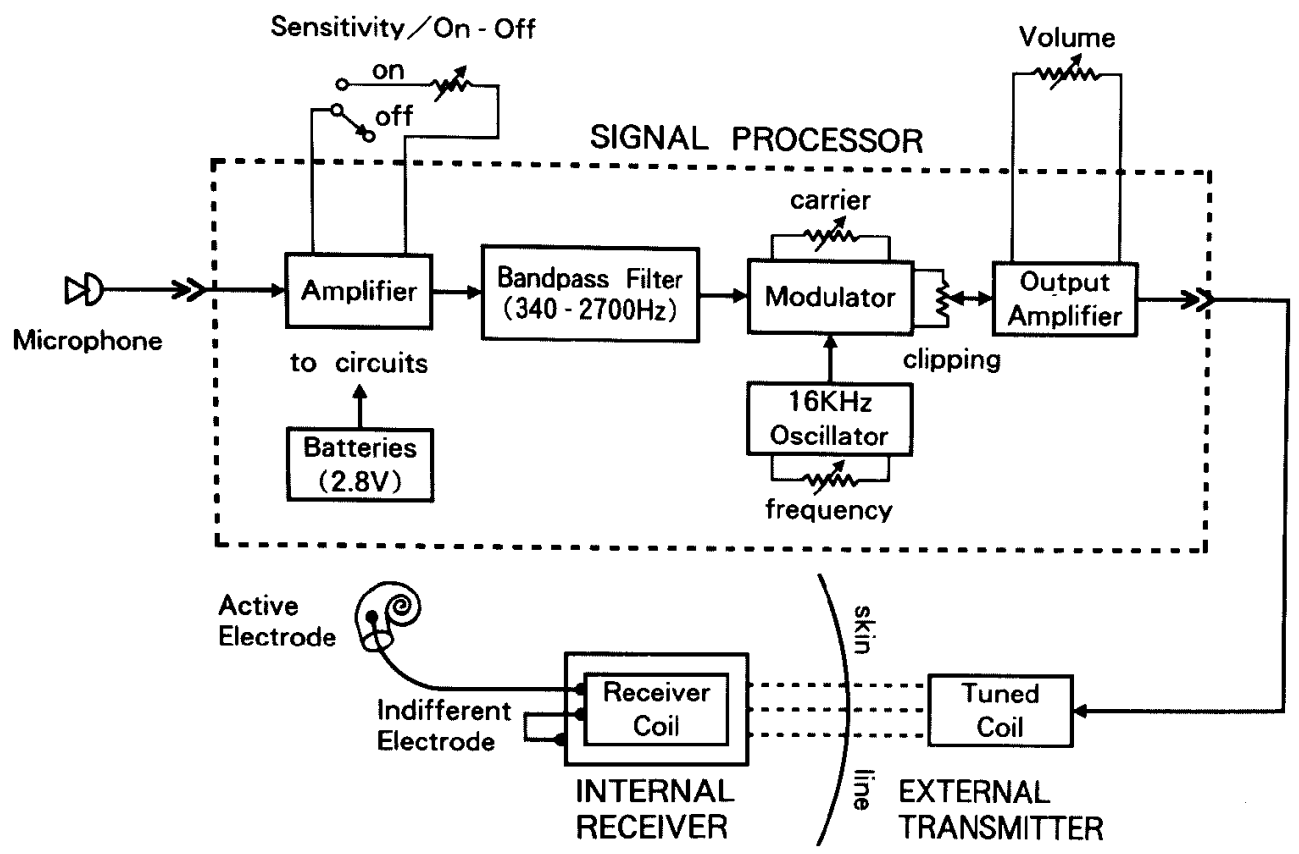

図 1 スリーエム社製シングルチャンネル人工内耳の回路図影.

ンで溶接密封され，それ自身が不関電極として働く。 刺激電極は蝸牛内に埋め込む $6 \mathrm{~mm} の$ 部分を除きシり コンチューブで被覆されている．この電極は数本の白 金の細線を捻って作られており，先端は球状で，内耳 組織を障害しないで捙入できるよう配慮されている。 マイクロホンからの入力信号はアナログ信号処理さ れ，340Hz から $2700 \mathrm{~Hz}$ の带域フイル夕を通した後， $16 \mathrm{kHz}$ の搬送波を振幅変調（AM）して体外コイルに 伝達される、体外コイルからの信号は電磁誘導で体内 コイルに誘導されるが, 後者に伝わる信号電圧は両者 間の距離に応じて減弱する，従って，実際に蝸牛神経 の刺激に負荷される電圧は体外装置の出力電圧上りも 小さい.

\section{III. 患者の選択}

現在のところ，以下のような条件がそろった場合が 人工内耳の適応と考えられる。

1）原則として成人で，言葉を覚えた後に高度難恥 となった場合。

2）両側の童ないし高度感音性難聴で, 補聴器によ っても実用聴力が得られない。

3）社会復㷌を強く望み,リハビリテーションに意 欲的てある。
4）試験的な内耳の電気刺激で聴覚反応の認められ ること.

5）中耳炎がないこと。あったとすれば充分に治療 されていること.

6）難聴の他に重篤な合併症のないこと。

7）生体内に埋め込まれる装置の素材に対してアレ ルギーのないこと。

最終的な適応決定にあたっては恥カレベル，原因疾 患, 失聴の時期, 難聴の進行度, 補聴器の使用歴など も考慮した。また，術後のリハビリテーションには家 族や周囲の人久の協力が必要なので，患者の家庭罟境 や社会環境なども調宵した。

\section{IV. 症例}

上記の条件を満たした 3 症例で人工耳植え込み 手術を行った，以下，これら症例の概要を述べる。な 㧍，手術に先だち，当大学倫理委員会の審查を受け， 了承を得た。

症例 137 歳 男性 商品配送係員

現病歴：幼少期より両側の中耳炎を繰り返す。昭和 47年加ら右耳に補聴器を使用。昭和54年に左鼓室形成 術を受けるも聴力は改善せず。この頃より右聴力も悪 化し，補聴器を使用しても全く聞こえなくなった，昭 
和 59 年, 再度, 左鼓室形成術を受けるも聴力は改善せ ずままた昭和 $60 ， 61$ 年に当科で段階的に鼓室形成術を 行ったが，聴力は襲の状態で改善しなかった，患者の 家庭および職場環境調查によるとコミュニケーション はすべて筆談で行われていた。何とか聞こえるように なりたいと人工内耳への期待は大きく，またりハビリ テーションへの意欲は高かった。昭和 62 年 2 月, 右耳 に人工内耳の植え込みを行う予定であったが，耳小骨 ならびに蝸牛空周囲に陳旧性の炎症病変があったので 乳突洞削開術にとどめ，8力月後の昭和62年10月，右 耳に人工内耳の植え込みを行った。

症例 259 歳 男性 運転手

現病歴：昭和54年に左耳の難聴,めまい発作があり, 発作を繰り返すうちに次第に進行して高度難聴となっ た。昭和57年に右耳の難聴, めまい発作が生じた。し かし, 高音域の難恥は残ったが進行せず, 聴力は落ち 着いていた。昭和62年 9 月, めまい発作とともに高度 難聴となった. 聴力は左 $90 \mathrm{~dB}$, 右 $105 \mathrm{~dB}$ と残聴がある ので補聴器の調整を行い装用の指導を行ったが満足で きず，本人の強い希望もあったため，昭和63年 3 月， 右耳に人工内耳の植え込みを行った.

\section{症例 335 歳 男性 郵便局員}

現病歴：7歳の時, 転倒して意識不明, その後, 左 耳の高度難聴に気づく．昭和62年 4 月, 髄膜炎に罹患 し意識不明となった。 1 週後に意識が回復した時, 両 側性の高度難恥に気づいた。当科受診時の恥力は右 $117 \mathrm{~dB}$, 左 $110 \mathrm{~dB}$ であった。患者は社会復帰の希望が 強く、リハビリテーションへの意欲も高かった。昭和 63年 7 月, 右耳に人工内耳の植え込み手術を行った.

\section{V。手術方法}

米国スリーエム社㧍よび House Ear Instituteの定 めた手引書に従った。術式の概要は以下の通りである. 手術は全身麻酔下に行う. 耳後部約 $3-4 \mathrm{~cm}$ の位置に 円孤状の切開を行い，体内コイルの位置を決定する。 次いで乳突洞削開術を行い，下鼓室を開放，正円空を 露出する．正円空に小孔を開け鼓室階内に電極を挿入 し，その上を筋膜片で覆いフィブリン糊 (Tissel $\left.{ }^{\circledR}\right)$ を 用いて電極を固定する。電極挿入操作は症例 $2 ， 3 て ゙$ は容易であったが, 症例 1 では正円空が骨性閉鎖して いたので，骨を $2-3 \mathrm{~mm}$ 削開して鼓室階を開空し電極 を挿入した。

\section{VI．リハビリテーションと術後の経過}

人工内耳による聴覚は正常者のように会話音声がそ のままの形で聞こえるのではなく，言語情報の一部の みが聞こえるものなので, リハビリテーションが非常 に重要な役割を果たす。我々の場合, 術後のリハビリ テーションは教育学者, 医師, 看護婦がチームを作り 協力して行った。リハビリテーションは手術創が落ち 着くと考えられる術後 3 週目頃より開始した. リ八ビ リテーションを短期間に集中的に行うか, 外来通院し ながら短時間ずつ行うかは，患者の住所や都合などを 考虑して決めた。

害際のリハビリテーションではシングルチャンネル 方式の人工内耳であることを考慮して, 次のような点 に特に留意した。1）音の強さと時間のパターンの認識 に重点を置いて指導する，2）読話は必要不可欠なの で，患者の意欲や動機づけを撌わない範囲で読話の訓 練を同時に進める、3）文脈の明らかな課題に基づいた 指導から始める。リハビリテーションの手順などの詳 細については，すでに報告した昂0)ので省略し，ここで は術後の経過と聴取能力の成績について報告する。

症例 1

術後 3 週閒目に体外部を装着させ，リハビリテーシ ヨンを開始した。初めて人工内耳により聞こえた音は, 患者によれば「ビィービィー」とか「ジージー」と聞 こえるにすぎないという。場面状況が設定された条件 での聴取可能音の範囲は, その後, 次第に増加した。 特に, 音の有無の明らかな断続音は恥取が容易であっ た.リハビリテーション開始 2 週目頃より訓練者の声 を特定化できるようになり，文のアクセントやイント ネーションが復唱できるようになった。人闻の装 用に慣れるに従い聴取能力は次第に向上した。予想さ れた通り読話の併用効果は大きかった，人工内耳のみ では聞き誤ったり、聞き取れない場合でも，読話を併 用すると日常的には不自由のないコミュニケーション が可能となった。ささら人工内耳の使用により周囲の 人々とのコミュニケーションが増加し性格にも変化が 見られた。これまで閉じこもりがちであった性格から 周囲の人にも関心が行き始め，明るい性格となった。 退院後は終日, 人工内耳を装着し, 日常生活に欠かせ ないものとして活用している，人工内耳による聴賞お よび読話併用による会話理解力は単語，文章において 著しく改善し，人工内耳装用の効果を認めた。また， 術前にみられた構音の乱れや音声ピッチの不自然さも 改善された。

症例 2 
人工内耳植え込み後 1 力月を経過した時期から体外 部を装着させ、りハビリテーションを開始した。初め て使用した時の印象は非常に良好であったが，基本的 には人工内耳のみで会話音声までが分かるものではな いとのことであった。リハビリテーション開始後 3 力 月の時点で, 人工内耳の装着時間は 1 日約 8 時間であ り，日常生活に欠かせないものとして活用している。 人工内耳による聴覚と読話の併用による会話理解力
は, 单語, 文章に扔いて著しく改善し, 術前の補聴器 装用時の結果と比べても優れていた。な扔，本例は術 前に残聴がみら机たが, 術後 3 力月目の人工内耳を植 え込んだ右側の聴力活術前と比べ約 $15 \mathrm{~dB}$ 程度低下し ていた。

症例 3

人工内耳植え込み後 3 週間目より体外部を装着さ せ、リハビリテーションを開始した。初めて人工内耳

表 1 術前㧍上び術後 3 力月目の読話能力ならびに聴取能力.

症例 1

(単位は\%)

\begin{tabular}{|c|c|c|c|c|c|c|}
\hline & \multicolumn{2}{|c|}{ 読話 } & \multicolumn{2}{|c|}{ 恥賞 } & \multicolumn{2}{|c|}{ 読話＋聴賞 } \\
\hline & 術前 & 術後 & $\begin{array}{c}\text { 術前 } \\
\text { (補聴器) }\end{array}$ & (人士術後 & $\begin{array}{c}\text { 術前 } \\
(\text { (補聴器 }+ \text { 読話) }\end{array}$ & $\begin{array}{c}\text { 術後 } \\
\text { (人工内耳十読話) }\end{array}$ \\
\hline 母音 & 100 & 100 & 0 & 20 & 100 & 100 \\
\hline 1 析数字 & 78 & 89 & 0 & 50 & 95 & 100 \\
\hline 単音節 & 15 & 38 & 0 & 10 & 35 & 45 \\
\hline 単語(選択肢なし) & 23 & 19 & 0 & 8 & 15 & 85 \\
\hline "l（選択肢あり） & 81 & 69 & 0 & 27 & - & 96 \\
\hline 文 & 38 & 17 & 0 & 22 & 38 & 89 \\
\hline
\end{tabular}

\begin{tabular}{|c|c|c|c|c|c|c|}
\hline & \multicolumn{2}{|c|}{ 読話 } & \multicolumn{2}{|c|}{ 聴賞 } & \multicolumn{2}{|c|}{ 読話+聴覚 } \\
\hline & 術前 & 術後 & $\begin{array}{c}\text { 術的i } \\
\text { (補聴器) }\end{array}$ & ( 術後 & $\begin{array}{c}\text { 術前 } \\
\text { (補聴器十読話) }\end{array}$ & $\begin{array}{c}\text { 術後 } \\
\text { (人工内耳十読話) }\end{array}$ \\
\hline 母音 & 100 & 100 & 25 & 20 & 100 & 100 \\
\hline 1 析数字 & 90 & 100 & 22 & 56 & 100 & 100 \\
\hline 単音節 & 30 & 67 & 0 & 10 & 50 & 55 \\
\hline 単語(選択肢なし) & 10 & 55 & 15 & 0 & 75 & 100 \\
\hline " (選択肢あり) & 100 & 65 & 25 & 70 & 100 & 100 \\
\hline 文 & 35 & 61 & 0 & 17 & 67 & 100 \\
\hline
\end{tabular}

症例 3

(単位は\%)

\begin{tabular}{|c|c|c|c|c|c|c|}
\hline & \multicolumn{2}{|c|}{ 読話 } & \multicolumn{2}{|c|}{ 㯖賞 } & \multicolumn{2}{|c|}{ 読話，恥賞 } \\
\hline & 術剖 & 術後 & $\begin{array}{c}\text { 術前 } \\
\text { (補聴器) }\end{array}$ & (人工内耳) & $\begin{array}{c}\text { 術前 } \\
\text { (補聴器十読話) }\end{array}$ & $\begin{array}{c}\text { 術後 } \\
\text { (人工内耳読話) }\end{array}$ \\
\hline 母音 & 100 & 100 & 10 & 10 & 100 & 100 \\
\hline 1 析数字 & 61 & 88 & 22 & 22 & 67 & 100 \\
\hline 単音節 & 30 & 40 & 0 & 0 & 25 & 50 \\
\hline 単語(選択肢なし) & 5 & 25 & 0 & 10 & 45 & 70 \\
\hline " （選択肢あり） & 75 & 95 & 15 & 15 & 75 & 90 \\
\hline 文 & 0 & 22 & 0 & 0 & 0 & 78 \\
\hline
\end{tabular}


を使用したときの印象は良好であったが，やはり基本 的には「ビィービィー」とか「ジージー」と聞こえる とのことであった。リハビリテーション開始後 3 力月 の時点で, 人工内耳の装着時間は 1 日約 8 時間である. 人工内耳による聴賞，および読話併用による会話理解 力は，単語，文章において著しく改善し，人工内耳装 用の効果が認められた。人工内耳使用に上る会話理解 力は, 術前の良聴耳（反対側）の補聴器装用下の結果 と比べても僭れていた。現在は退院し，職場復帰の準 備を行っている。

\section{VII. 人工内耳に上る聴取能力}

3 症例の術前および術後 3 力月目の母音,一析数字,
単音節，単語，文の聴取能の結果を表 1 にまとめた。 検査方法の詳細はここでは省略するが，いずれの症例 でも人工内耳と読話の併用により術前の補聴器使用時 よりも良好な結果が得られた。

Speech Tracking Test ${ }^{11)}$ (復唱検查)を指標とした 術後の恥取能力の改善経過を図 2 に示した.この検査 は検者が題材を読み，患者がそれを復唱する。これを 10 分間行い，1分間に何文節復唱できるかを求める。 復唱険查では話題によって理解能に個人差があるの で、ここでは題材に童話を用いた。いずれの症例も読 話能力が改善したこともあるが, 術前と比べ徐々に成 績は改善し,術後 $3 \sim 4$ 力月で20〜25文節/分まで復唱 できるようになった。しかし 4 カ月目以後の向上は著

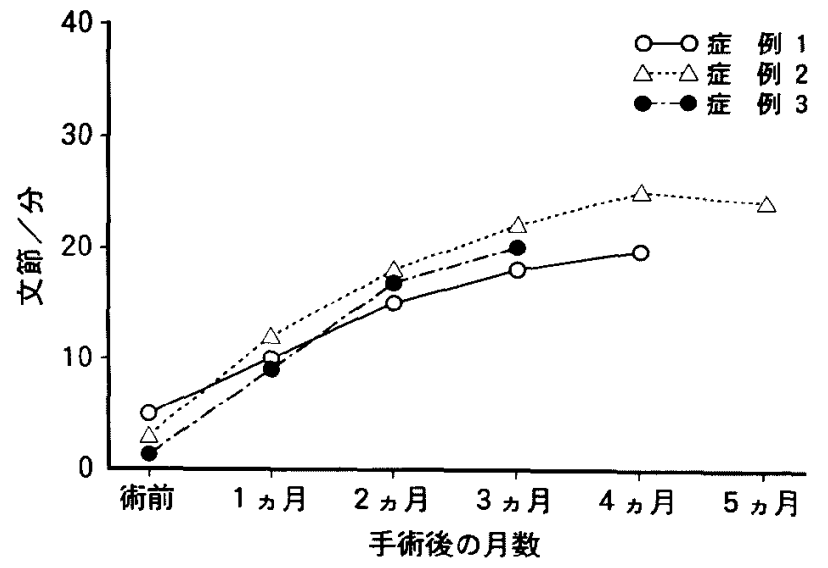

図 2 読話と人工内耳の併用による復唱検查成績の経過。㭘查の題材には童話 を用いた. 術後の聴取能力は徐々に改善し, $3 \sim 4$ 力月で $20 \sim 25$ 文節/分 にまで向上した。

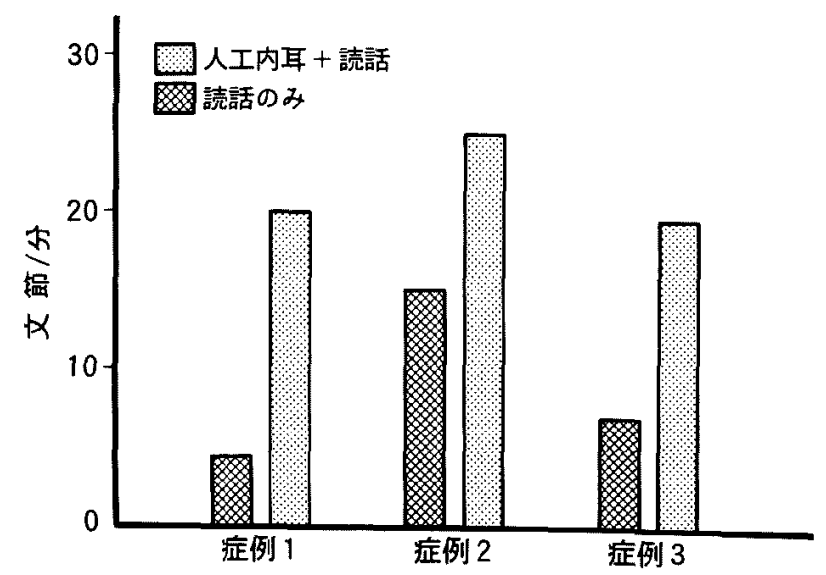

図 3 読話のみと人工内耳併用時の復唱検査成績. 症例 1,2 は術後 4 力月目, 症例 3 は 3 力月目の成績を示す。人工内耳と読話の併用により聴取能力 は著明に向上した。 
しくなく，頭打ちになる傾向にあった．図 3 は術後 3 $\sim 4$ 力月目の読話のみと人工内耳と読話を併用した時 の復唱検査の結果を示したものである。患者の意欲を 損ねないよう人工内耳のみの検査は行っていない。症 例 2 を除き, 読話のみでは聴取能力は良くないが, 人 工内耳の併用でいずれも聴取能力は著明に向上した。

\section{VIII． 副作用ならびに合併症}

今回 3 症例に人工内耳の植え込みを行ったが，自賞 的にも全く副作用や合併症を認めなかった，耳鳴りに ついてはいずれも術前と同じ程度であり，めまいは症 例 2 で術後一過性に生じたが，その後は植え込まれた 電極周囲を強く圧迫した時にファとする感じを訴える のみで，問題となることはなかった。

\section{IX. 考按}

人工内耳には大別してシングルチャンネル方式とマ ルチチャンネル方式とがある．音声の理解のためには 後者の方が優れているとされているが, 前者にも後者 との比較で, 1）内耳に埋め込さ電極が短いので㨉入が 容易で内耳組織を障害しにくい,2）構造が単純なので 故障が起こりにくい，3）将来, より高性能の装置が開 発された場合も取り替えが容易である,4）比較的安価 である，といった長所がある．今回，植え込みを行っ たアルファ型人工内耳はシングルチャンネル方式では あるが，いずれの患者も聴覚を回復し，会話音声や環 境音などの情報を耳から得ることができるようになっ た、とりかけ読話を併用すれば著明な聴取能力の改善 が認められ，会話音の聴取に有効であった。

現在いくつかの人工内耳が実用化されているが，機 種聞の性能の比較のためには㭘査法の統一が必要であ る。米国などでは検査法の基準化が進められている が，言語構造の異なる日本語では欧米の検査法をその まま用いることはできない，現在のところ，人工内耳 による聴取能力の評価に母音・子音の弁別検查や単語 の聞き取り検査の他に，復唱検査が広く用いられてい る。復唱検查は読話能力を含めた言語聴取能を評価す るのに適しているが，実際には復唱させる題材によっ て成績に差があり, 我々の症例でも童話では成績は良 いものの新聞記事では低かった。本邦での術後成績の 報告で仿題材として童話 ${ }^{23344)}$ ないし小学校高学年程度 の物語5)が用いられているので，本論文では童話によ る成績を示した，它の結果，図2，3にも示したよう に術後 $3 \sim 4$ 力月の時点で $20 \sim 25$ 文節/分まで復唱で
きるようになった。船坂ら゙ は Nucleus 社製マルチチ ヤンネル方式の人工内耳の手術成績の報告の中で，リ ハビリテーション開始後 3 力月目の読話併用での復唱 検查の結果は，4例中最もよい例は32.2文節/分, 悪い 例は20.1文節/分であったと報告している。また伊藤 $ら^{6)} も$ 同じ機種を用い, 良い時の成績は32文節/分であ ったと報告している。従って検查方法に多少の違いが あるとしても，シングルチャンネル方式人工内耳によ る言語理解能はマルチチャンネル方式の悪い例とほほ 同じ程度ということになる。

このように復唱蚞査では両者間にそれ程の差はみら れないが, 音声情報のみによる聴取能ではシングルチ ャンネル型は劣っていた。とりわけ母音の理解能では 大きな差がみられた。これは Nucleus 社製人工内耳が 特に母音聴取能に留意して設計されているからであろ う。いずれにしろ，人工内耳で聞こえる音声情報はマ ルチチャンネル方式の方が多く, 言語聴取能の点では 明らかに優位にある。しかしながらマルチチャンネル 方式人工内耳はすべての症例に適応があるわけではな い. 例えば，蝸牛が高度に骨化して長い電極が挿入で きない場合や，蝸牛神経の残存が極端に少なくマルチ チャンネルの効果が期待できない場合などはシングル チャンネル型の適応となりうる。

今回唡討を行ったスリーエム社製アルファ型人工内 耳は単にアナログ処理を行っているにすぎず，高度の 信号処理を行光ばシングルチャンネル方式でもかなり の程度まで言語聴取能を高めうる可能性がある。現在 の装置はアナログ信号を内耳に送り込む比較的単純な 方式であるが, 圧縮音声信号を用いたり ${ }^{13)}$, 音声信号内

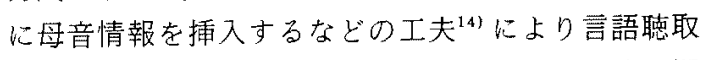
能が向上することが報告されている。今後の研究が期 待される。

\section{$\mathrm{X}$. ま とめ}

シングルチャンネルカ式のアルファ型人工内耳を 3 例ひ高度難聴者に植え込みリハビリテーションを行つ た。その結果, 人工内耳は塑の治療法として有効な手 段であり，また適切な注意を払えば手術は安全に行え， 副作用は掞こらないことを確認した。術後は集中的に リハビリテーションを行った。言語聴取能は月を追つ て向上したが, 検查成績をみる限り $3 \sim 5$ 力月後頃に 頭打ちになる傾向にあった。最終的には，読話を併用 すれば日常生活に不自由のない程度にまで言語聴取能 は改善した。しかしながら，人工内耳のみでは言語聴 
取能は不十分で,とりわけ母音や単語の理解能は低く, この方式による人工内耳では読話の併用が不可欠と思 われた。

\section{参考文献}

1）神尾友和，八木聰明，関根修二，小林 謙，恩地 豊： Cochlear Implant $の 一$ 一例. Audiol Jpn 24: 475-476, 1981.

2）八木聰明, 山越順子, 小林 謙, 神尾友和: Cochlear Implant 症例の聴性誘発反応. Audiol Jpn 29：194$198,1986$.

3）船坂宗太郎，細谷 睦，林原成子，高橋 整，湯川久美 子他：22チャンネル Cochlear Implant-そのシステ ム紹介と本格的言語訓練前の話声聴取能について一. 日耳鼻 89：1070-1076，1986.

4）船坂宗太郎, 林原成子, 高橋 整, 湯川久美子, 初鹿信 一 : 22 Channel Cochlear Implant 患者の言語聴取能. 日耳鼻 $90: 995-1003 ， 1987$.

5）船坂宗太郎, 高橋 整, 湯川久美子, 城間将江, 熊川孝 三: 22 Channel Cochlear Implant 患者の語音聴取能 とその生理学的考察. 耳喉頭頸 $60: 283-289,1988$.

6）伊藤寿一, 土師知行, 川野通夫, 竹内真理子, 本庄 螈: 人工内耳手術とリハビリテーション。耳番臨床 81 1563-1568, 1988

7) 広田栄子, 小寺一興, 加我君孝, 鈴木淳一: 人工内耳適 応症例に扝けるリハビリテーションの評価. Audiology Jpn $31:$ 343-344, 1988.

8) Fretz RJ, Fravel RP : Design and function : A physical and electrical description of the $3 \mathrm{M}$ House cochlear implant system. Ear and Hearing 6 (supplement 3) : 14S-19S, 1985.

9）高橋信雄：人工中耳抽よび人工内耳による聴取能力回 復のための訓練。電子情報通信学会音声研究会資料 SP87-74 : 21-27, 1987.

10）高橋信雄, 柳原尚明, 暁 清文, 佐藤英光: シングルチ ャンネル型人工内耳での聴取能力の検討. Audiology Jpn $31: 339-340,1988$.

11) De Filippo CL, Scott BL : A method for training and evaluating the reception of ongoing speech. J Acoust Soc Am 63 : 1186-1192, 1978.

12) Brackmann $D E:$ Recommendation for the reporting of preoperative testing and postoperative results in cochlear implantation. Otolaryngol Head Neck Surg $97:$ 519-521, 1987.

13) Hochmair ES, Hochmair-Desoyer IJ : Percept elicited by different speech-coding strategies. Ann N Y Acad Sci 405: 268-279, 1983.

14）高橋国広, 松島純一, 伊福部 達, 熊谷雅彦, 寺山吉彦: 単電極型人工内耳のためのホルマント情報伝達に関す 了実験的研究. 耳鼻臨床 $81: 453-459,1988$.

患者のリハビリテーションに際して御指導を頂いた愛媛 大学教育学部就心理, 高橋信雄助教授に感謝します。本論文 の要旨は第14回日耳鼻四国四県地方部会 (高知)において報 告した.

(原稿受付 1989年 1 月 5 日)

別刷請求先 $=791-02$ 愛媛県温泉郡重信町大字志津川 愛媛大学医学部耳鼻咽喉科学教室 暁 清文 